\title{
Physical Fitness of Children with Special Needs: Aiken Validation Game Materials
}

\author{
Sumaryanti Sumaryanti ${ }^{1, *}$ Dapan Dapan ${ }^{1,}$ Bernadeta Suhartini ${ }^{1,}$ \\ Margono Margono ${ }^{1}$ \\ ${ }^{I}$ Faculty of Sport Sciences, Universitas Negeri Yogyakarta, Yogyakarta, Indonesia \\ *Corresponding author.Email: sumaryanti@uny.ac.id
}

\begin{abstract}
Many physical education teachers for teachers with special needs use non-game-based learning material models in improving students' physical fitness related to health. The game is one of the important factors in physical education material to improve physical fitness related to health. The purpose of the study was to validate the game material to improve the physical fitness of children with special needs. The research method uses mixed qualitative and quantitative methods. Qualitative methods were used to draft the game material model, while the quantitative approach was used to test expert agreement. The research subjects were documents and seven experts. Data were collected using the Delphi technique and were analyzed using the Aiken formula. The results show that all aspects of the running train game material model, the wood saw game material model, the tire pumping game material model, and the waving palm tree game material model are considered to have high content validity.
\end{abstract}

\section{Keywords: Physical fitness, Content validation, Children with special needs}

\section{INTRODUCTION}

Children with disabilities are engaged in less physical activity than their peers [1], [2]. Performing regular physical activity will benefit bone health [3], [4], improve psychological health [5], [6], improve body composition [7], fitness, and promote social engagement [8] for children, including children with disabilities. There is an added therapeutic benefit to doing routine activities for children with disabilities [9]. Children with disabilities often experience delays in gross motor development, less skill in balance, coordination, and poor cardiovascular fitness compared to their peers [10]. Lower participation reflects additional barriers faced by persons with disabilities, including physical, personal, social, and the environment [11], [12]. All children with special needs have the potential to be improved by participating in physical activity. The conceptual model of Physical Activity for Persons with Disabilities can help improve social relationships and personal roles with their environment and health. Barriers to physical activity have been studied more comprehensively to participation, including the lack of knowledge, skills, child preferences, fears, parental behavior, negative attitudes towards disability, inadequate facilities, the lack of transportation, lack of program and staff capacity, and cost [13].
Increasing physical fitness related to health is one of the important factors that must be done at all ages because this can be beneficial for the prevention and reduction of the risk of degenerative diseases [14], [15]. These benefits are evident if health-related fitness is fostered from school-age [16]. Health-related physical fitness consists of cardiorespiratory fitness, namely the ability to perform with the whole body for long periods of time; flexibility, or range of motion of a joint or group of joints; muscle strength, which indicates the maximum amount of force that the muscle can exert against any resistance in a short period of time; and muscular endurance, describing the ability of a muscle to sustain multiple contractions over a long period of time [17]. The results show that the value of physical fitness related to adolescent health can improve cardiovascular function [18], movement skills [19], or can reduce obesity [20], [21]. One way to improve physical fitness related to health by building active habits from an early age is the main strategy for developing health-related physical fitness, not only in the short term but also over time. Active habits in children aged four years to adulthood have been researched. The results show a positive relationship between physical activity and healthrelated physical fitness [22], [23], [24], [25], [26], [27]. Therefore, physical education (PE), especially when planned successfully, provides more opportunities for everyone to be active compared to 
out-of-school sports facilities, which has another potential limitation [28]. The exact benefits of physical fitness on health-related fitness are demonstrated in the large literature, which outlines the effects of physical exercise on increasing physical fitness [29], or improving mental health [30]. However, the positive influence of Physical Education on health is mediated by several factors, including the style of the teacher and the choice of learning materials. In fact, the approach of teachers and teachers of children with special needs still uses the traditional approach to Physical Education, teachers of children with special needs tend to use a strict exercise routine strategy, has been associated with a lower perceived quality of life, as well as less happy children [31]. There is evidence that traditional instructional styles, less or not gamebased, while most teachers still use traditional teaching styles, lead to lower, zero, or negative physical education effects on health-related fitness-related variables [32], [33], [34]. In contrast, the successful PE model seems to rely on a more game-based approach, as several authors have pointed out in previous work. For example, Dominguez and del Campo [35] compared the Sports Education model to the traditional Physical Education model, emphasizing the importance of experimenting with repetition to internalize learning in this setting. Physical fitness is the main focus of the work of Lavrin et al. [36], which distinguishes game-based programs from traditional ones. At the end of the implementation semester, students in the game-based program showed higher fitness than their traditional group counterparts. This finding was confirmed by Ceballos Gurrola et al. [37], who conducted a ball game program with elementary school children, in which it obtained a significant improvement in the metabolic profile of students in the experimental group compared to those in the control group. Based on the facts above, it is clear that the game is one of the important factors in physical education material to improve physical fitness related to health [38]. Therefore, this study aimed to validate the game material to improve physical fitness related to the health of children with special needs in elementary school.

\section{METHODS}

The study used a mixture of qualitative and quantitative methods. The research subjects were documents and seven experts. This research procedure consists of two steps: the first step is using a literature review approach to drafting game material for the physical fitness of children with special needs - data collection was using Mendeley to collect data on textbooks and journals from the Pubmed and Google Scholar databases. Then, the researchers identified the articles based on the research topic, namely: game material for the physical fitness of children with special needs. After identifying the articles, then the next steps were filtering the articles and choosing appropriate articles, with the aforementioned criteria in 2010 and those relevant to the topic. Data analysis was done using a qualitative thematic approach.

The second step is to use an evaluation research design. The data collection technique uses the Delphi technique [39]. Data analysis was conducted using the Aiken formula [40], elaborated as follows.

$\mathrm{V}=\mathrm{S} /[\mathrm{n}(\mathrm{c}-1)$

Information:

$\mathrm{V}=$ Aiken validity coefficient value,

$\mathrm{S}=$ rating scale value minus 1 ,

$\mathrm{n}=$ number of assessors or experts used in validation, $\mathrm{c}=$ highest score in the rating scale.

\section{RESULTS}

Based on the thematic analysis, four game media products were produced as physical education learning materials for physical fitness for children with special needs, as follows: (1) a draft of a running train game model, (2) a draft of wood saw game model, (3) a draft of a tire pumping game model, and (4) the draft model of the waving palm tree game.

Indicators used by Experts in assessing the instruments on the draft model of the running train game material, the draft of the wood saw game material model, the tire pumping game material model draft, the waving palm tree game material model draft, are as follows: (1) suitability of the game material with learning objectives, (2) suitability of game material with basic competencies, (3) clarity of game rules, (4) clarity of language and images. The results of the assessment were analyzed using the Aiken formula, which results on the data presented in Table 1, Table 2, Table 3, and Table 4.

Based on Table 1, on aspect 1, the suitability of game material with learning objectives shows the Aiken's V coefficient value of 0.90 , aspect 2 of the suitability of game material with Basic Competence shows Aiken's V coefficient value of 0.86 , aspect 3 clarity of game rules shows Aiken's coefficient value $\mathrm{V}$ of 0.90 , aspect 4 of language clarity and pictures shows Aiken's V coefficient value of 0.80 . Aiken's V coefficient value ranges from $0-1$. Because the minimum standard Aiken's V coefficient value for this research is 0.76 , it can be said that all aspects show high content validity. In other words, all experts have high agreement on all aspects assessed. 
Table 1. Train Running Game Material Model

\begin{tabular}{|c|c|c|c|c|c|c|c|c|}
\hline \multirow{2}{*}{ Evaluator } & \multicolumn{2}{|c|}{ Aspect 1 } & \multicolumn{2}{c|}{ Aspect 2 } & \multicolumn{2}{c|}{ Aspect 3 } & \multicolumn{2}{c|}{ Aspect 4 } \\
\cline { 2 - 9 } & Score & $s$ & Score & $s$ & Score & $s$ & Score & $S$ \\
\hline $\mathbf{1}$ & 4 & 3 & 4 & 3 & 4 & 3 & 4 & 3 \\
\hline $\mathbf{2}$ & 4 & 3 & 3 & 2 & 3 & 2 & 3 & 2 \\
\hline $\mathbf{3}$ & 3 & 2 & 3 & 2 & 4 & 3 & 4 & 3 \\
\hline $\mathbf{4}$ & 4 & 3 & 4 & 3 & 4 & 3 & 3 & 2 \\
\hline $\mathbf{5}$ & 4 & 3 & 4 & 3 & 4 & 3 & 4 & 3 \\
\hline $\mathbf{6}$ & 3 & 2 & 3 & 2 & 3 & 2 & 3 & 2 \\
\hline $\mathbf{7}$ & 4 & 3 & 4 & 3 & 4 & 3 & 3 & 2 \\
\hline $\mathbf{S}$ & & $\mathbf{1 9}$ & & $\mathbf{1 8}$ & & $\mathbf{1 9}$ & & $\mathbf{1 7}$ \\
\hline V & & $\mathbf{0 . 9 0}$ & & $\mathbf{0 . 8 6}$ & & $\mathbf{0 . 9 0}$ & & $\mathbf{0 . 8 0}$ \\
\hline
\end{tabular}

Table 2. Woodsaw Game Material Model

\begin{tabular}{|c|c|c|c|c|c|c|c|c|}
\hline \multirow{2}{*}{ Evaluator } & \multicolumn{2}{|c|}{ Aspect 1 } & \multicolumn{2}{c|}{ Aspect 2 } & \multicolumn{2}{c|}{ Aspect 3 } & \multicolumn{2}{c|}{ Aspect 4 } \\
\cline { 2 - 9 } & Score & $s$ & Score & $s$ & Score & $s$ & Score & $S$ \\
\hline $\mathbf{1}$ & 4 & 3 & 4 & 3 & 4 & 3 & 3 & 2 \\
\hline $\mathbf{2}$ & 4 & 3 & 3 & 2 & 3 & 2 & 4 & 3 \\
\hline $\mathbf{3}$ & 3 & 2 & 3 & 2 & 4 & 3 & 4 & 3 \\
\hline $\mathbf{4}$ & 4 & 3 & 4 & 3 & 4 & 3 & 3 & 2 \\
\hline $\mathbf{5}$ & 3 & 3 & 3 & 2 & 4 & 3 & 3 & 2 \\
\hline $\mathbf{6}$ & 3 & 2 & 3 & 2 & 3 & 2 & 4 & 3 \\
\hline $\mathbf{7}$ & 4 & 3 & 4 & 3 & 4 & 3 & 3 & 2 \\
\hline $\mathbf{S}$ & & $\mathbf{1 8}$ & & $\mathbf{1 7}$ & & $\mathbf{1 9}$ & & $\mathbf{1 7}$ \\
\hline $\mathbf{V}$ & & $\mathbf{0 . 8 6}$ & & $\mathbf{0 . 8 0}$ & & $\mathbf{0 . 9 0}$ & & $\mathbf{0 . 8 0}$ \\
\hline
\end{tabular}

Based on Table 2, aspect 1 of the suitability of game material with learning objectives shows the Aiken's V coefficient value of 0.86 , aspect 2 of the suitability of game material with Basic Competence shows Aiken's V coefficient value of 0.80 , aspect 3 clarity of game rules shows Aiken's coefficient value $\mathrm{V}$ of 0.90 , and aspect 4 of language clarity and pictures shows Aiken's V coefficient value of 0.80 . Aiken's V coefficient value ranges from $0-1$. Because the minimum standard Aiken's $\mathrm{V}$ coefficient value for this study is 0.76 , it can be said that all aspects show high content validity. In other words, all experts have high agreement on all aspects assessed.

Table 3. Game Material Models for Pumping Tires

\begin{tabular}{|c|c|c|c|c|c|c|c|c|}
\hline \multirow{2}{*}{ Evaluator } & \multicolumn{2}{|c|}{ Aspect 1 } & \multicolumn{2}{c|}{ Aspect 2 } & \multicolumn{2}{c|}{ Aspect 3 } & \multicolumn{2}{c|}{ Aspect 4 } \\
\cline { 2 - 9 } & Score & $s$ & Score & $s$ & Score & $s$ & Score & $S$ \\
\hline $\mathbf{1}$ & 4 & 3 & 4 & 3 & 3 & 2 & 4 & 3 \\
\hline $\mathbf{2}$ & 3 & 3 & 3 & 2 & 3 & 2 & 4 & 3 \\
\hline $\mathbf{3}$ & 3 & 2 & 3 & 2 & 4 & 3 & 4 & 3 \\
\hline $\mathbf{4}$ & 4 & 3 & 3 & 2 & 3 & 2 & 3 & 2 \\
\hline $\mathbf{5}$ & 3 & 2 & 3 & 2 & 4 & 3 & 4 & 3 \\
\hline $\mathbf{6}$ & 3 & 2 & 3 & 2 & 3 & 2 & 3 & 2 \\
\hline $\mathbf{7}$ & 4 & 3 & 4 & 3 & 3 & 2 & 3 & 2 \\
\hline $\mathbf{S}$ & & $\mathbf{1 7}$ & & $\mathbf{1 6}$ & & $\mathbf{1 6}$ & & $\mathbf{1 8}$ \\
\hline V & & $\mathbf{0 . 8 0}$ & & $\mathbf{0 . 7 6}$ & & $\mathbf{0 . 7 6}$ & & $\mathbf{0 . 8 6}$ \\
\hline
\end{tabular}

Based on Table 3, on aspect 1 the suitability of game material with learning objectives shows the Aiken's V coefficient value of 0.80 , aspect 2 of the suitability of game material with Basic Competence shows Aiken's V coefficient value of 0.76 , aspect 3 clarity of game rules, shows Aiken's coefficient value $\mathrm{V}$ of 0.76 , and aspect 4 of language clarity and pictures shows Aiken's V coefficient value of 0.86 .
Aiken's V coefficient value ranges from $0-1$. Because the minimum standard Aiken's V coefficient value for this research is 0.76 , it can be said that all aspects show high content validity. In other words, all experts have high agreement on all aspects assessed.

Table 4. Material Model for the Waving Palms Game

\begin{tabular}{|c|c|c|c|c|c|c|c|c|}
\hline \multirow{2}{*}{ Evaluator } & \multicolumn{2}{|c|}{ Aspect 1 } & \multicolumn{2}{c|}{ Aspect 2 } & \multicolumn{2}{c|}{ Aspect 3 } & \multicolumn{2}{c|}{ Aspect 4 } \\
\cline { 2 - 9 } & Score & $S$ & Score & $s$ & Score & $s$ & Score & $S$ \\
\hline $\mathbf{1}$ & 3 & 2 & 4 & 3 & 4 & 3 & 4 & 3 \\
\hline $\mathbf{2}$ & 3 & 2 & 3 & 2 & 3 & 2 & 4 & 3 \\
\hline $\mathbf{3}$ & 3 & 2 & 3 & 2 & 3 & 2 & 4 & 3 \\
\hline $\mathbf{4}$ & 4 & 3 & 4 & 3 & 4 & 3 & 3 & 2 \\
\hline $\mathbf{5}$ & 4 & 3 & 4 & 3 & 3 & 2 & 4 & 3 \\
\hline $\mathbf{6}$ & 3 & 2 & 3 & 2 & 3 & 2 & 3 & 2 \\
\hline $\mathbf{7}$ & 3 & 2 & 4 & 3 & 4 & 3 & 3 & 2 \\
\hline $\mathbf{S}$ & & $\mathbf{1 6}$ & & $\mathbf{1 8}$ & & $\mathbf{1 7}$ & & $\mathbf{1 8}$ \\
\hline V & & $\mathbf{0 . 7 6}$ & & $\mathbf{0 . 8 6}$ & & $\mathbf{0 . 8 0}$ & & $\mathbf{0 . 8 6}$ \\
\hline
\end{tabular}

Based on Table 4, aspect 1 of the suitability of game material with learning objectives shows the Aiken's V coefficient value of 0.76 , aspect 2 of the suitability of game material with Basic Competence shows Aiken's V coefficient value of 0.86 , aspect 3 clarity of game rules shows Aiken's coefficient value $\mathrm{V}$ of 0.80 , and aspect 4 of language clarity and pictures shows Aiken's V coefficient value of 0.86 . Aiken's V coefficient value ranges from $0-1$. Because the minimum standard Aiken's V coefficient value for this research is 0.76 , it can be said that all aspects show high content validity. In other words, all experts have high agreement on all aspects assessed.

\section{CONCLUSION}

Based on the results and discussion of the research, it is concluded that the running train game material model, the wood saw game material model, the tire pumping game material model, and the waving palm tree game material model have high content validity to be used as physical education learning in improving physical fitness for children with special needs. Physical education teachers can use this material model in an effort to improve the physical fitness of children with special needs. In addition, this material model needs to be continued with research to find out the effectiveness of this material model to improve physical fitness.

\section{ACKNOWLEDGMENT}

The author would like to thank UNY for funding this group's research. 


\section{REFERENCES}

[1] Carlon S, Shields N, Dodd K, Taylor N. Differences in habitual physical activity levels of young people with cerebral palsy and their typically developing peers: syatematic review. Disabil Rehabil. 2013; 35:647-55.

[2] Frey G, Stanish HI, TempleVA. Physical activity of youth with intellectual disability: review and research agenda. Adapt Phys Actv Q. 2008: 25:95-117.

[3] Brandey M, Pearce G, Naughton G, Sullivan C, Bass S, Beck T, et al. Moderate exercise during growth in prepubertal boys: Changes in bone mass, size, volumetric density, and bone strength: a controlled prospective study. J Bone Miner Res. 1998; 13: 1814-21.

[4] Morris FL, Naughton GA, Gibbs JL, Carlson JS, Wark JD. Prospective ten-month exercise intervention in premenarcheal girls: positive effects on bone and lean mass, J Bone miner Res. 1997;12(9):1453-62.

[5] Wilkinson PF. Disabled children and integrated play environments. Res Rev. 1983;10:20-8

[6] Tros SG. Discussion paper for the develomentof recommendations for childrens and youths participation in health promotingphysical activity. Canberra: Ageing AGDoHa;2005.

[7] LeMURA L, Maziekkas M. Factors that alter body fat, body mass and fat-free mass in pediatric obesity. Med Sci Sports Exerc. 2002;34:487-96.

[8] Jobling A. Life be in it: lifestyle choices for active leisure. Donw Syndr Res pract. 2001;6(3): $117-22$.

[9] Damiano D. Activity, Activity: Rethinking Our Physical Therapy Approach to Cerebral palsy. Phys Ther. 2006; 86: 1534-40.

[10] Horvat M, Pitetti KH, Croce R. Isokinetic torque, average power, and flexion/extension ratios in nondisabled adults and adults with mental retardation. J Orthopaedic \& Sports Physical Therapy. 1997;25(6):395-9.

[11] Heah T, Case T, McGuire B, Law M. Successful participation: The lived experience among children with disabilities.Can J Occup Ther. 2007;74(1): 38-47.

[12] Van Der Ploeg H, van der Beek A, van der Woude L, van Mechelen W. Physical activity for people with a disability: a conceptual model. Sports Med. 2004; 34:639-49.
[13] Shields N, Synnot A, Barr M. Perceived barriers and facilitators to physical activity for children with disability: a systematic review. Br J Sports Med. 2012; 46:989-97.

[14] Marcus-Varwijk, A.E; Peters, L.L.; Visscher, T.L.S.; Smits, C.H.M.; Ranchor, A.V.; Slaets, J.P.J. (2020). Impact of a nurse-led health promotion intervention in an aging population: Resuults from a quasi-experimental study on the " Community HealthConsultation Offices for Seniors", J. Aging Health 2020, 32, 83-94. [CeossRef][Pubmed]

[15] Razeghi, S.; Amiri, P.; Mohebbi, S.Z.; Kharazifard, M.J. (2020). Impact of health promotion interventions on early childhood caries prevention in children aged 2-5 years receiving dental treatment under general anesthesia. Front. Public Health 2020, 8, 6. [CrossRef]

[16] National Center for Chronic Disease Prevention and Health Promotion. Promoting Health for Children and Adolescents. Available online: https://www.cdc.gov/chronicdisease/resources/pu blications/factsheets/ children-health.htm (accessed on 12 May 2020).

[17] Chen, W.; Hammond-Bennett, A.; Hypnar, A.; Mason, S.(2018). Health-related physical fitness and physical activity in elementary school students. BMC Public Health 2018, 18, 195. [CrossRef] [PubMed]

[18] Baumgartner, L.; Weberruss, H.; Oberhoffer, R.; Schulz, T. (2020). Vascular structure and function in children and adolescents: What impact do physical activity, health-related physical fitness, and exercise have? Front. Pediatr. 2020, 8, 103. [CrossRef] [PubMed]

[19] Rainer, P.; Jarvis, S. (2020). Fundamental movement skills and their relationship with measures of health-related physical fitness of primary school children prior to secondary school transition: A Welsh perspective. Education 3-13 2020, 48, 54-65. [CrossRef]

[20] Garcia-Hermoso, A.; Alonso-Martinez, A.M.; Ramirez-Velez, R.; Izquierdo, M. (2020). Effects of exercise intervention on health-related physical fitness and blood pressure in preschool children: A systematic review and meta-analysis of randomized controlled trials. Sports Med. 2020, 50, 187-203. [CrossRef] [PubMed]

[21] Parra, L.N.; Canto, E.G.; Guillamon, A.R. (2020). Values of health-related physical fitness in adolescents from 14 to 17 years of age; relationship with weight status. Retos 2020, 37, 215-221.Appelqvist-Schmidlecher, K.; Vaara, J.; 
Hakkinen, A.; Vasankari, T.; Makinen, J.; Mantysaari, M. Pendahuluan

[22] Kyrolainen, H. (2018). Relationship between youth sports participation and mental health in young adulthood among Finnish males. Am. J. Health Promot. 2018, 32, 1502-1509. [CrossRef]

[23] Ekblom-Bak, E.; Ekblom, O.; Andersson, G.; Wallin, P.; Ekblom, B. (2018). Physical education and leisure-time physical activity in youth are both important for adulthood activity, physical performance, and health. J. Phys. Act. Health 2018, 15, 661-670. [CrossRef]

[24] Cocca, A.; Liukkonen, J.; Mayorga-Vega, D.; Viciana, J. (2014). Health-related physical activity levels in Spanish youth and young adults. Percept. Mot. Skills 2014, 118, 247-260. [CrossRef]

[25] Fraser, B.J.; Schmidt, M.D.; Huynh, Q.L.; Dwyer, T.; Venn, A.J.; Magnussen, C.G.(2017). Tracking of muscular strenght and power from youth to young adulthood: Longitudinal findings from the Childhood Determinants of Adult Health Study. J. Sci. Med. Sport 2017, 20, 927931. [CrossRef]

[26] Cho, D.; Park, C.L. Smoking and sedentary behavior changes from adolescence to emerging adulthood: A multilevel modeling perspective. Prev. Med. 2017, 101, 223-228. [CrossRef] [PubMed]

[27] Lee, D.M.; Shiroma, E.J.; Lobelo, F.; Puska, P.; Blair, S.N.; Katzmarzyk, P.T.(2012). Effect of physical inactivity on major non-communicable diseases worldwide: An analysis of burden of disease and life expectancy. Lancet 2012, 380, 219-229. [CrossRef]

[28] Fernandez-Prieto, I.; Gine-Garriga, M.; Canet Velez, O. (2019). Barriers and motivations perceived by adolescentes related to physical activity. Qualitative study through discussion groups. Rev. Esp. Salud. Publica 2019, 93, 12.

[29] Pasek, M.; Szark-Eckardt, M.; Wilk, B.; Zuzda, J.; Zukowska, H.; Opanowska, M.; Kuska, M.; Drozdz, R.; Kusmierczyk, M.; Saklak, W.; et al. (2020). Physical fitness as a part of the health and well-being of students participating in physical education lessons indoors and outdoors. Int. J. Environ. Res. Public Health 2020, 17, 309. [CrossRef]

[30] Triaca, L.M.; Frio, G.S.; Franca, M.T.A. (2019). A gender analysis of the impact of physical education on the mental health of Brazilian schoolchildren. SSM Popul. Health 2019, 8, 100419. [CrossRef]

[31] Tilga, H.; Hein, V.; Koka, A.; Hamilton, K.; Hagger, S.M. (2019). The role of teachers' controlling behaviour in physical education on adolescents' health-related quality of life: Test of a conditional process model. Educ. Psychol. 2019, 39, 862-880. [CrossRef]

[32] Cale, L. Physical Education's journey on the road to health. Sport Educ. Soc. 2020. [CrossRef]

[33] Griban, G.; Porntenko, K.; Yavorska, T.; Bezpaily, S.; Bublei, T.; Marushchak, M.; Pustoliakova, L.; Andreychuk, V.; Tkachenko, P.; Zhukovsky, Y.; et al. (2019). Non-traditional means of physical training in middle school physical education classes. Int. J. Appl. Exerc. Physiol. 2019, 8, 221-229.

[34] Pan, Y.H.; Huang, C.H.; Lee, I.S.; Hsu, W.T. (2019). Comparison of learning effects of merging TPSR respectively with Sport Education and traditional teaching model in high school physical education classes. Sustainability 2019, 11, 2057. [CrossRef]

[35] Dominguez, Y.S.; del Campo, D.G.D. (2018). Teachers' and students' perceptions of the HIIT application in physical education. Sport Education vs traditional approach. Agor. Educ. Fis. Deporte 2018, 20, 133-161. [CrossRef]

[36] Lavrin, H.; Sereda, I.; Kucher, T.; Grygus, I.; Cieslicka, M.; Napierala, M.; Muszkieta, R.; Zukow, W. (2019). Efficiency means the game Ringo the classroom physical education. Int. J. Appl. Exerc. Physiol. 2019, 8, 3. Available online: http://ijaep.com/Journal/397Article\%20File\%202-1986-1-2-20190723.pdf (accessed on 18 May 2020).

[37] Ceballos Gurrola, O.; Lomas Acosta, R.; Enriquez Martinez, M.; Ramirez, E.; Medina Rodriguez, R.E.; Enriquez Reyna, M.C.; Cocca, A. (2020). Impact of a health program on metabolic profile and self-concept in adolescents with obesity. Retos 2020, 38, 452-458.

[38] Hartati, S.C.Y.; Priambodo, A.; Djawa, B.; Prakoso, B.B. (2018). Building Cooperation Interpersonal Skill in Physical Education Lessons through Traditional Game. In Proceedings of the International Seminar on Public Health and Education 2018, Semarang, Indonesia,8-9 May 2018; Ali, M.A.Windraswara, R., Eds.; ISPHE: Semarang, Indonesia, 2018; pp. 245-248. 
[39] McMillan SS, King M, Tully MP. (2016). How to use the nominal group and Delphi techniques. Int J Clin Pharm. 38(3):655-62

[40] Aiken, L. R. (1985) Three Coefficients foe Analyzing The Reliability, and Validity of Ratings.Educational and Psychological Measurement, 45, 131-142

[41] Polit, D. F., Beck, C. T., \& Owen, S. V. Is the CVI an acceptable indicator of content validity? Appraisal and recommendations. Research in nursing \& health. 2007. 30(4), 459-467
[42] Kowsalya, D. N., Lakshmi, H. V., \& Suresh, K. P. (2012). Development and Validation of a Scale to assess Emotional Maturity in Mild Intellectually Disabled Children. Language in India. 2012. 12(6).Landis,

[43] Wilson, F. R., Pan, W., Schumsky, D. A.( 2012). Recalculation of the critical values for Lawshe's content validity ratio. Measurement and Evaluation in Counseling and Development. 2012 . 45, 197-210. doi:10.1177/0748175612440286. 